\title{
The Prevalence of Depression among Adult Asthmatic Patients in Jizan Region, Saudi Arabia
}

\author{
Mohamed Ahmed Sumaily*1, Salwa Tayel ${ }^{2}$, Elsiddig Mohamed Noureldin ${ }^{3}$
}

${ }^{1}$ Department of Public Health Jizan - MOH, ${ }^{2}$ Department of Family and Community Medicine KSU, ${ }^{3}$ National Center for Vector - Borne Diseases Jizan - MOH, Saudi Arabia

*Corresponding author: Mohamed Ahmed Sumaily, Mobile: +966558812067, E-mail: mohamedsumaily@gmail.com

\begin{abstract}
Background: Depression is an important issue in asthma. Uncover depression in asthmatic patients has important implications for identifying patients and suitable treatment of these patients this will improve quality of life, decrease medication intake and decrease hospitalization.

Objective: The aim of this study was to determine the prevalence of depression among adult asthmatic patients in Jizan region, Saudi Arabia.

Patients and methods: Cross-sectional study that was conducted in Jizan region at the chest diseases hospital. 270 (18$90 \mathrm{yrs}$.) asthmatic patients were recruited. The questionnaire including socio-demographic data, clinical risk factors of asthma, assessment of asthma by using asthma control test (ACT) and assessment of depression by using Patient Health Questionnaire-9 (PHQ-9).

Results: Out of 270 adult asthmatic patients, 255 responded (94.4\%). The mean age of patients was $41.03 \pm 15.893$ years. The prevalence of depression among adult asthmatic patients was $32.9 \%$. By multivariate analysis the lower education level [elementary school or below (Odds ratio 3.219 (95\% CI; 1.443-7.177)] and longer asthma duration (22 years and above) Odds ratio 2.065 (95\% CI; 1.089-3.916) were independently associated with the development of depression in adult patients with asthma.

Conclusion: The study showed that there was a high prevalence of depression among adult asthmatic patients in Jizan region, Saudi Arabia. The higher prevalence of depression was associated with lower education level, longer asthma duration, poor control of asthma and among married subjects. Screening for depression in adult asthmatic patients should be emphasized in primary health care centers, chest clinics and in hospitals. Adult asthmatic patients should be motivated to comply with asthma treatment.
\end{abstract}

Keywords: Depression, Asthma, Saudi Arabia.

\section{INTRODUCTION}

Asthma is one of the noncommunicable diseases. It is influencing 235 million individuals around the world and caused 383000 deaths in 2015 according to the latest WHO estimates ${ }^{(\mathbf{1})}$. In Saudi Arabia, asthma is the main causes of hospitalization ${ }^{(2)}$. In 2013 a national household survey found that asthma prevalence in Saudi adults was $4.05 \%$ out of 525,794 Saudis aged 15 years or older (from a total of 12,000 households survey and 10,735 participants) ${ }^{(3)}$.

Depression is a common mental disease in the world that causes low mood, loss of interest, feelings down, trouble of sleep, disturbed appetite, feeling tired, and bad concentration ${ }^{(4)}$. The burden of depression is rising globally. It is the major reason of disability globally. Women are affected more than men by depression. Depression can cause suicide at worst status about 800000 people die every year due to suicide. Although there is a treatment for depression, fewer than half of affected patients in the world (in different countries, fewer than 10\%) get treatment. Some barriers to health care encompass inadequate mental health resource, poor of health care staff, insufficient assessment and social stigma related to mental illness. In countries of different income level, depressed people are not correctly diagnosed and treated ${ }^{(5)}$.
In Saudi Arabia, a study conducted at King Abdul Aziz Medical City-National Guard, in the biggest three primary health care centers in Riyadh, the prevalence of depression was found high $49.9 \%$ from ages 18 to 65 years ${ }^{(6)}$. The multiple underlying risk factors for depression such as chronic diseases, low income, job loss, female sex, divorced or widowed, single, younger age and lack of self-esteem (7). Some of the consequences of depression destroys the quality of life, makes relationships difficult and affects the ability to work and risk of suicide ${ }^{(8)}$. Psychiatric diseases are a neglected part in the care of physical disorder and management, especially asthma where patients possibly get scared and worried during the acute attack at the time they sense that they might suffocate ${ }^{(9)}$.

In 2015 a study by Ciprandi et al. ${ }^{(10)}$ showed that the prevalence of depression was $11 \%$ in 263 patients with asthma. The study demonstrated that depression is common and relevant comorbidities in asthmatic patients. A study in 2017 at three cities of Saudi Arabia (Riyadh, Jeddah, and Alkhobar) showed that the prevalence of depression with asthma patients was $20 \%$ (30 cases among 150 patients), including 50 asthmatic patients from every city ${ }^{(11)}$. The depression is an important issue in asthma and some of the consequences of the depression in asthmatic patients are associated with decrease in asthma-specific quality of life and greater medication intake and more hospitalization ${ }^{(\mathbf{1 2})}$. 
To the best of our knowledge, a few studies in Saudi Arabia and no previous study in Jizan region has been conducted to determine the prevalence of depression among adult asthmatic patients and related factors in health facilities.

The present study aimed to investigate the prevalence of depression among adult asthmatic patients and related factors in Jizan region, Saudi Arabia.

\section{PATIENTS AND METHODS}

The study was conducted in Jizan region at the Chest Diseases Hospital at the outpatient clinic.

Inclusion Criteria: All Saudi patients aged 18 years or older who was registered at the chest diseases hospital and diagnosed as asthmatic patients.

Exclusion Criteria: Patients aged less than 18 years and the admitted patients in the hospital. Patients who received psychiatric treatment elsewhere and are on treatment at time of the study.

Data collection was conducted in outpatient's clinic for the asthmatic patients who had appointments and patients were selected randomly from medical records then medical staff notified patient about the questionnaire and after agreement we interviewed them. Variables: Depression and factors, which may affect depression including socio-demographic factors, clinical risk factors of asthma and asthma control status. Sample size: For calculation of the sample size for this study the following formula was used ${ }^{(13)}$ :

$$
n=\frac{Z^{2} P(1-P)}{d^{2}}
$$

Where (n) is the sample size, ( $\mathrm{z}$ ) is the statistic corresponding to the level of confidence, ( $p$ ) is expected prevalence (that can be obtained from previous studies), (d) is the precision.

Given: $d=0.05, Z=1.96$ for $95 \%$ confidence level, $\mathrm{p}=0.20$ based on ${ }^{(\mathbf{1 1})}$.

Then $\mathrm{n}=(1.96)^{2}(0.20)(0.80) /(0.05)^{2}=245$.

This sample size (245) increase to 270 to compensate for expected non-response rate of $10 \%$.

\section{Ethical permission:}

A written permission was obtained from the chest diseases hospital in Jizan region. A written Arabic informed consent was obtained from every patient. This study was approved on 19 December 2017 (IRB number E-17-2773) by the institutional review boards of King Saud University College of Medicine.

\section{Assessment of Asthma Control Test:}

The Asthma Control Test (ACT) is standardized, valid and reliable to assess the level of asthma control with good internal reliability with a Cronbach's $\alpha$ of 0.85 . It had a sensitivity of $71 \%$ and specificity of $71 \%^{(14)}$. ACT Contains 5 items during the past 4 weeks about: the effect of asthma on duties, shortness of breath, the effect of symptoms on awakening from Table (1): The baseline characteristic. sleep, need for nebulizer medication and evaluation of asthma control. Each item includes 5 response options, responses for every one of the 5 items are a score ranging from 5 (poor control of asthma) to 25 (complete control of asthma). A cutoff score of 19 or less recognizes patients with uncontrolled asthma. While a cut-point score of 20 or more has been defined as controlled asthma ${ }^{(\mathbf{1 5})}$. The Arabic version of Asthma Control Test was used in the present study ${ }^{(16)}$.

\section{Assessment of depression:}

Depression was assessed using the Patient Health Questionnaire-9 (PHQ-9) and it is standardized valid and reliable measure of depression with excellent internal reliability with a Cronbach's $\alpha$ of 0.89 . It had high sensitivity of $88 \%$ and specificity of $88 \%$ compared to other questionnaires. The PHQ-9 is a nineitem and assesses each of the nine criteria on a scale from 0 (not at all) to 3 (nearly every day). The PHQ-9 score range from 0 to 27 and score of 10 or greater is considered depression, where a score less than 10 is considered no depression. The questionnaire included nine questions over the last two weeks how often have you been bothered by this problem: little interest in doing things, hopeless, troubling in asleep, feeling tired, poor appetite, feeling bad about self, trouble concentration, trouble in moving and thoughts about hurting self in some way ${ }^{(17)}$. The Arabic version of "Patient Health Questionnaire 9" to assess depression was used in the present study ${ }^{(18)}$.

The study period: This study was conducted between October 2017 and April 2018.

\section{Statistical analysis}

All statistical analyses were performed using SPSS 21.0 software (SPSS Inc., Chicago, IL, USA). Values were means \pm standard deviation (SD), frequencies and percentage (\%). The independent T-test was used to compare between numerical variables associated with depression. The Chisquare test was used to compare between categorical variables associated with depression. Multivariate analysis was used to calculate the odds ratio for factors predicting depression among asthmatic patients. The confidence interval was set at $95 \%$ and a $\mathrm{P}$ value equal or less than 0.05 was considered statistically significant.

\section{RESULT \\ Patient Characteristics:}

Mean age of patients was $41.03 \pm 15.893$ with range of $18-90$ years, $54.5 \%$ were males. The baseline characteristics are summarized in table (1). $42 \%$ of patients were elementary school or below and $67.1 \%$ were not working. Almost $72.5 \%$ were married. Moreover, almost $63.9 \%$ were rural residence. About $45.1 \%$ had asthma less than 10 years and above $78.8 \%$ without hypertension also about $87.5 \%$ without diabetes. 
https://ejhm.journals.ekb.eg/

\begin{tabular}{|c|c|}
\hline Demographic characteristic & $\begin{array}{l}\text { Values * } \\
(\mathrm{N}=255)\end{array}$ \\
\hline $\begin{array}{l}\text { Age in years } \\
\text {-Mean } \pm \text { SD } \\
\text {-Range in years }\end{array}$ & $\begin{array}{c}41.03 \pm 15.893 \\
18-90\end{array}$ \\
\hline $\begin{array}{l}\text { Gender } \\
\text {-Male } \\
\text {-Female }\end{array}$ & $\begin{array}{l}139(54.5 \%) \\
45.5 \%)) 116\end{array}$ \\
\hline $\begin{array}{l}\text { Education } \\
\text {-Elementary school or below } \\
\text {-Intermediate or secondary school } \\
\text {-College or above- }\end{array}$ & $\begin{array}{l}107(42 \%) \\
83(32.5 \%) \\
25.5 \%) 65\end{array}$ \\
\hline $\begin{array}{l}\text { Occupation } \\
\text {-Working } \\
\text {-Not working }\end{array}$ & $\begin{array}{c}84(32.9 \%) \\
171(67.1 \%)\end{array}$ \\
\hline $\begin{array}{l}\text { Marital status } \\
\text {-Single } \\
\text {-Married }\end{array}$ & $\begin{array}{l}70(27.5 \%) \\
185(72.5 \%)\end{array}$ \\
\hline $\begin{array}{l}\text { Residence } \\
\text {-Rural } \\
\text {-Urban }\end{array}$ & $\begin{array}{c}163(63.9 \%) \\
92(36.1 \%)\end{array}$ \\
\hline $\begin{array}{l}\text { Asthma duration } \\
\text {-Less than } 10 \text { years } \\
\text {-From } 11 \text { to } 21 \text { years } \\
\text {-From } 22 \text { and above }\end{array}$ & $\begin{array}{c}115(45.1 \%) \\
56(22 \%) \\
84(32.9 \%)\end{array}$ \\
\hline $\begin{array}{l}\text { Hypertension } \\
\text {-Yes } \\
\text {-No }\end{array}$ & $\begin{array}{c}54(21.2 \%) \\
201(78.8 \%)\end{array}$ \\
\hline $\begin{array}{l}\text { Diabetes } \\
\text {-Yes } \\
\text {-No }\end{array}$ & $\begin{array}{c}32(12.5 \%) \\
223(87.5 \%)\end{array}$ \\
\hline
\end{tabular}

*Values are mean \pm standard deviation, numbers, frequencies and percentages (\%).

Asthma control test (ACT) among the asthmatic patients:

Table (2) showed the result of assessment of asthma using Asthma control test (ACT). We found that 70.2\% have uncontrolled asthma. Whereas $29.8 \%$ have controlled asthma. Also, the mean asthma control test (ACT) score was 13.68 \pm 6.150 . 
Table (2): Asthma control test (ACT) among asthmatic patients.

\begin{tabular}{|c|c|}
\hline Asthma control test & $\begin{array}{l}\text { Values * } \\
(\mathrm{N}=255)\end{array}$ \\
\hline $\begin{array}{l}\text { 1-In the past } 4 \text { weeks, how much of the time did your asthma keep } \\
\text { you from getting as much done at work, school or at home? } \\
\text { All of the time } \\
\text { Most of the time } \\
\text { Some of the time } \\
\text { A little of the time } \\
\text { None of the time }\end{array}$ & $\begin{array}{c}28(11 \%) \\
54(21.2 \%) \\
64(25.1 \%) \\
55(21,6 \%) \\
54(21.2 \%)\end{array}$ \\
\hline $\begin{array}{l}\text { 2-During the past } 4 \text { weeks, how often have you had shortness of } \\
\text { breath? } \\
\text { More than Once a day } \\
\text { Once a day } \\
3 \text { to } 6 \text { times a week } \\
\text { Once or twice a week } \\
\text { Not at all }\end{array}$ & $\begin{array}{l}54(21.1 \%) \\
41(16.1 \%) \\
36(14.1 \%) \\
86(33.7 \%) \\
38(14.9 \%)\end{array}$ \\
\hline $\begin{array}{l}\text { 3-During the past } 4 \text { weeks, how often did your asthma symptoms } \\
\text { (wheezing, coughing, shortness of breath, chest tightness or pain) } \\
\text { wake you up at night or earlier than usual in the morning? } \\
4 \text { or more nights a week } \\
2 \text { to } 3 \text { nights a week } \\
\text { Once a week } \\
\text { Once or twice } \\
\text { Not at all }\end{array}$ & $\begin{array}{l}40(15.7 \%) \\
68(26.7 \%) \\
33(12.9 \%) \\
72(28.2 \%) \\
42(16.5 \%)\end{array}$ \\
\hline $\begin{array}{l}\text { 4- During the past } 4 \text { weeks, how often have you used your rescue } \\
\text { inhaler or nebulizer medication (such as albuterol)? } \\
3 \text { or more times per day } \\
1 \text { or } 2 \text { times per day } \\
\text { from } 2 \text { or } 3 \text { times per week } \\
\text { Once a week or less } \\
\text { Not at all }\end{array}$ & $\begin{array}{c}57(22.4 \%) \\
52(20.4 \%) \\
46(18 \%) \\
56(22 \%) \\
44(17.3)\end{array}$ \\
\hline $\begin{array}{l}\text { 5- How would you rate your asthma control during the past } 4 \\
\text { weeks? } \\
\text { Not Controlled at All } \\
\text { Poorly Controlled } \\
\text { Somewhat Controlled } \\
\text { Well Controlled } \\
\text { Completely Controlled }\end{array}$ & $\begin{array}{c}57(22.4 \%) \\
52(20.4 \%) \\
46(18 \%) \\
56(22 \%) \\
44(17.3 \%)\end{array}$ \\
\hline $\begin{array}{l}\text { Classification of asthma ** } \\
\text {-Uncontrolled } \leq 19 \\
\text { Controlled } \geq 20-\end{array}$ & $\begin{array}{c}179(70.2 \%) \\
76(29.8 \%)\end{array}$ \\
\hline $\begin{array}{l}* * * A C T \text { score } \\
- \text { Mean } \pm \text { SD }\end{array}$ & $13.68 \pm 6.150$ \\
\hline
\end{tabular}

*Values are frequencies and percentages (\%).

*** Asthma control status was evaluated by the asthma control test (ACT) score (uncontrolled, ACT $\leq 19$; controlled, ACT $\geq 20$ ),

$* * * \mathrm{ACT}=$ asthma control test.

Depression assessed using the Patient Health Questionnaire-9 (PHQ-9) among adult asthmatic patients: Table (3) showed assessment of depression using PHQ-9 among adult asthmatic patients. We found one third (32.9\%) having depression $\geq 10$ among adult asthmatic patients. while tow third $67.1 \%$ non-depressed $\leq 9$. 
Table (3): Depression assessed using the Patient Health Questionnaire-9 (PHQ-9) among adult asthmatic patients.

\begin{tabular}{|c|c|}
\hline Depression & $\begin{array}{l}\text { Values* } \\
(\mathrm{N}=255)\end{array}$ \\
\hline \multicolumn{2}{|l|}{ Over the last 2 weeks, how often have you been bothered by any of the following problems? } \\
\hline $\begin{array}{l}\text { 0-Little interest or pleasure in doing things. } \\
\text { Not at all } \\
\text { Several days } \\
\text { More than half the days } \\
\text { Nearly every day }\end{array}$ & $\begin{array}{c}72(28.2 \%) \\
132(51.8 \%) \\
24(9.4 \%) \\
27(10.6 \%)\end{array}$ \\
\hline $\begin{array}{l}\text { b- Feeling down, depressed, or hopeless. } \\
\text { Not at all } \\
\text { Several days } \\
\text { More than half the days } \\
\text { Nearly every day }\end{array}$ & $\begin{array}{c}79(31 \%) \\
124(48.6 \%) \\
33(12.9 \%) \\
19(7.5 \%) \\
\end{array}$ \\
\hline $\begin{array}{l}\text { c- Trouble falling or staying asleep, or sleeping too much. } \\
\text { Not at all } \\
\text { Several days } \\
\text { More than half the days } \\
\text { Nearly every day }\end{array}$ & $\begin{array}{c}40(15.7 \%) \\
127(49.8 \%) \\
45(17.6 \%) \\
43(16.9 \%)\end{array}$ \\
\hline $\begin{array}{l}\text { d- Feeling tired or having little energy. } \\
\text { Not at all } \\
\text { Several days } \\
\text { More than half the days } \\
\text { Nearly every day }\end{array}$ & $\begin{array}{c}57(22.4 \%) \\
116(45.5 \%) \\
37(14.5 \%) \\
45(17.6 \%)\end{array}$ \\
\hline $\begin{array}{l}\text { e- Poor appetite or overeating. } \\
\text { Not at all } \\
\text { Several days } \\
\text { More than half the days } \\
\text { Nearly every day }\end{array}$ & $\begin{array}{c}75(29.4 \%) \\
117(45.9 \%) \\
30(11.8 \%) \\
33(12.9 \%)\end{array}$ \\
\hline $\begin{array}{l}\text { f- Feeling bad about yourself }- \text { or that you are a failure or have let yourself or your } \\
\text { family down. } \\
\text { Not at all } \\
\text { Several days } \\
\text { More than half the days } \\
\text { Nearly every day }\end{array}$ & $\begin{array}{c}130(51 \%) \\
97(38 \%) \\
15(5.9 \%) \\
13(5.1 \%)\end{array}$ \\
\hline $\begin{array}{l}\text { g- Trouble concentrating on things, such as reading the newspaper or watching } \\
\text { television } \\
\text { Not at all } \\
\text { Several days } \\
\text { More than half the days } \\
\text { Nearly every day }\end{array}$ & $\begin{array}{c}109(42.7 \%) \\
111(43.5 \%) \\
20(7.8 \%) \\
15(5.9 \%)\end{array}$ \\
\hline $\begin{array}{l}\text { h- Moving or speaking so slowly that other people could have noticed? Or the opposite } \\
\text { - being so fidgety or restless that you have been moving around a lot more than usual. } \\
\text { Not at all } \\
\text { Several days } \\
\text { More than half the days } \\
\text { Nearly every day }\end{array}$ & $\begin{array}{c}114(44.7 \%) \\
100(39.2 \%) \\
24(9.4 \%) \\
17(6.7 \%)\end{array}$ \\
\hline $\begin{array}{l}\text { 0- Thoughts that you would be better off dead or of hurting yourself in some way. } \\
\text { Not at all } \\
\text { Several days } \\
\text { More than half the days } \\
\text { Nearly every day }\end{array}$ & $\begin{array}{c}185(72.5 \%) \\
62(24.3 \%) \\
5(2 \%) \\
3(1.2 \%)\end{array}$ \\
\hline $\begin{array}{l}\text { Classification of depression } * * \\
\text {-Depression } \geq 10 \\
\text {-No depression } \leq 9\end{array}$ & $\begin{array}{c}84(32.9 \%) \\
171(67.1 \%)\end{array}$ \\
\hline
\end{tabular}

** Depression was determined by a PHQ-9 score, the score $\geq 10$ is considered depression, while a score $\leq 9$ is considered no depression, * Values are expressed as frequencies and percentages (\%). PHQ-9, patient health questionnaire-9. 
The prevalence and comparison between depressed and non-depressed patients with asthma

Using PHQ-9 classification for depression, the prevalence of depression was 32.9. Table (4) showed education was $51.4 \%$ of elementary school or below, which was associated with depressed $(\mathrm{p}<0.001)$, while $36.8 \%$ of married patients had depression ( $p=0.035) .28 .7 \%$ of patients who had asthma less than 10 years were depressed $(p<0.001)$. The mean ACT score was lower in depressed patients $(12.32 \pm 5.230, \mathrm{p}=0.013)$.

Table (4): Comparison between depressed and non-depressed patients with asthma.

\begin{tabular}{|c|c|c|c|}
\hline \multirow[b]{2}{*}{ Parameters } & \multicolumn{3}{|c|}{ All patients } \\
\hline & $\begin{array}{c}\text { Depressed } \\
(\mathrm{n}=84) \\
\geq 10\end{array}$ & $\begin{array}{c}\begin{array}{c}\text { Non-depressed } \\
(\mathbf{n}=171) \\
\leq 9\end{array} \\
\end{array}$ & P value \\
\hline $\begin{array}{l}\text { Age in years } \\
\text {-Mean } \pm \text { SD }\end{array}$ & $43.23 \pm 17.241$ & $39.95 \pm 15.123$ & 0.122 \\
\hline $\begin{array}{l}\text { Gender } \\
\text {-Male } \\
\text {-Female }\end{array}$ & $\begin{array}{l}44(31.7 \%) \\
40(34.5 \%)\end{array}$ & $\begin{array}{l}95(68.3 \%) \\
76(65.5 \%)\end{array}$ & 0.632 \\
\hline $\begin{array}{l}\text { Education } \\
\text {-Elementary school or below }(\%) \\
\text {-Intermediate or secondary school }(\%) \\
\text {-College or above }(\%)\end{array}$ & $\begin{array}{l}55(51.4 \%) \\
17(20.5 \%) \\
12(18.5 \%)\end{array}$ & $\begin{array}{l}52(48.6 \%) \\
66(79.5 \%) \\
53(81.5 \%)\end{array}$ & $0.001>$ \\
\hline $\begin{array}{l}\text { Occupation } \\
\text {-Working }(\%) \\
\text {-Not working }(\%)\end{array}$ & $\begin{array}{c}26(31 \%) \\
58(33.9 \%)\end{array}$ & $\begin{array}{c}58(69 \%) \\
113(66.1 \%)\end{array}$ & 0.636 \\
\hline $\begin{array}{l}\text { Marital status } \\
\text {-Single }(\%) \\
\text {-Married }(\%) \\
\end{array}$ & $\begin{array}{l}16(22.9 \%) \\
68(36.8 \%)\end{array}$ & $\begin{array}{c}54(77.1 \%) \\
117(63.2 \%) \\
\end{array}$ & 0.035 \\
\hline $\begin{array}{l}\text { Residence } \\
\text {-Rural (\%) } \\
\text {-Urban }(\%)\end{array}$ & $\begin{array}{l}54(33.1 \%) \\
30(32.6 \%)\end{array}$ & $\begin{array}{c}109(66.9 \%) \\
62(67.4 \%)\end{array}$ & 0.932 \\
\hline $\begin{array}{l}\text { Asthma duration } \\
\text {-Less than } 10 \text { years }(\%) \\
\text {-From } 11 \text { to } 21 \text { years }(\%) \\
\text {-From } 22 \text { years and above }(\%)\end{array}$ & $\begin{array}{l}33(28.7 \%) \\
10(17.9 \%) \\
41(48.8 \%)\end{array}$ & $\begin{array}{l}82(71.3 \%) \\
46(82.1 \%) \\
43(51.2 \%)\end{array}$ & $0.001>$ \\
\hline $\begin{array}{l}\text { Hypertension } \\
\text {-Yes }(\%) \\
\text {-No }(\%) \\
\end{array}$ & $\begin{array}{l}22(40.7 \%) \\
62(30.8 \%)\end{array}$ & $\begin{array}{c}32(59.3 \%) \\
139(69.2 \%)\end{array}$ & 0.170 \\
\hline $\begin{array}{l}\text { Diabetes } \\
\text {-Yes }(\%) \\
\text {-No }(\%)\end{array}$ & $\begin{array}{l}13(40.6 \%) \\
71(31.8 \%)\end{array}$ & $\begin{array}{c}19(59.4 \%) \\
152(68.2 \%)\end{array}$ & 0.323 \\
\hline $\begin{array}{l}\text { ACT score } \\
- \text {-Mean } \pm \text { SD }\end{array}$ & $12.32 \pm 5.230$ & $14.35 \pm 6.465$ & 0.013 \\
\hline
\end{tabular}

Depression was determined by a PHQ-9 score $\geq 10$, Values are expressed as Means \pm SD, frequencies and percentage (\%). ACT, asthma control test; PHQ-9, patient health questionnaire-9.

Association between depression and asthma outcomes:

All patients were classified into uncontrolled asthma or controlled asthma groups based on ACT score, which were summarized in Table (5). Depression was significantly more prevalent in the uncontrolled group than in the controlled group $(39.1 \%$ versus $=10.333, \mathrm{p}<0.001) 218.4 \%$, chi-squared $\chi$.

Table (5): Association between depression and asthma outcomes according to asthma control status.

\begin{tabular}{|c|c|c|c|}
\hline Variable & $\begin{array}{c}\text { Depression } \\
(\mathbf{n = 8 4})\end{array}$ & $\begin{array}{c}\text { Non depression } \\
(\mathbf{n = 1 7 1})\end{array}$ & P value \\
\hline $\begin{array}{c}\text { Uncontrolled } \\
(\mathrm{n}=179)\end{array}$ & $70(39.1 \%)$ & $109(60.9 \%)$ & 0.001 \\
\hline $\begin{array}{c}\text { Controlled } \\
(\mathrm{n}=76)\end{array}$ & $14(18.4 \%)$ & $62(81.6 \%)$ & \\
\hline
\end{tabular}

Asthma control status was evaluated by the asthma control test (ACT) score (uncontrolled, ACT $\leq 19$; controlled, ACT $\geq 20$ ), values were frequencies and percentages $(\%)$. 


\section{Multivariate analysis predictors of depression among asthmatic patients:}

The multivariate logistic analysis was used to identify a predictor of increased risk for clinical depression. The results revealed that lower education level (elementary school or below, Odds ratio 3.219, (95\% CI; 1.443-7.177, $\mathrm{p}=0.004)$ and longer asthma duration (22 years and above, Odds ratio $2.065(95 \%$ CI: $1.089-3.916, \quad p=0.026$ ) were independently associated with the development of depression in adult patients with asthma (Table 6).

Table (6): Predictive factors of depression in patients with asthma.

\begin{tabular}{|c|c|c|}
\hline Variable & $\begin{array}{c}\text { Odds ratio }(95 \% \\
\text { CI) }\end{array}$ & $\begin{array}{c}\mathbf{P} \\
\text { value }\end{array}$ \\
\hline $\begin{array}{l}\text { Education * } \\
\text {-Elementary school } \\
\text { or below } \\
\text {-Intermediate or } \\
\text { secondary school }\end{array}$ & $\begin{array}{c}3.219 \\
(1.443-7.177) \\
0.887 \\
(0.376-2.096)\end{array}$ & $\begin{array}{l}0.004 \\
0.785\end{array}$ \\
\hline $\begin{array}{l}\text { Marital status** } \\
\text {-Married }\end{array}$ & $\begin{array}{c}0.943 \\
(0.453-1.963) \\
\end{array}$ & 0.876 \\
\hline $\begin{array}{l}\text { Asthma duration**: } \\
\text {-From } 11 \text { to } 21 \\
\text { years } \\
\text {-From } 22 \text { years and } \\
\text { above }\end{array}$ & $\begin{array}{c}0.679 \\
(0.295-1.563) \\
2.065 \\
(1.089-3.916) \\
\end{array}$ & $\begin{array}{l}0.363 \\
0.026\end{array}$ \\
\hline ACT score & $\begin{array}{c}0.964 \\
(0.917-1.013)\end{array}$ & 0.149 \\
\hline
\end{tabular}

CI, confidence interval; ACT, asthma control test.

* The reference of education variable was college or above. $* *$ The reference of the martial variable was single. $* * *$ The reference of asthma duration variable was less than 10 years.

\section{DISCUSSION}

Many studies found an association between asthma and depression where depression has a great burden on asthmatic patients. It leads to decrease in the quality of life and increase medication intake and more hospitalization ${ }^{(10)}$. A few studies in Saudi Arabia and no previous study in Jizan region has been conducted to determine the prevalence of depression among adult asthmatic patients and related factors in health facilities.

We conducted this study by using the PHQ-9 questionnaire and confirmed a high prevalence (32.9\%) of depression among adult asthmatic patients. The current study is consistent with the study of Choi $\boldsymbol{e t} \boldsymbol{a l}$. ${ }^{(19)}$ in Korea that used similar questionnaire (PHQ-9) to assess the depression. They found that the prevalence of depression was $16.8 \%$ in patients with asthma, which is lower than this study. This lower prevalence reported in Korea may be due to their sample that included patients with better control asthma (high mean asthma control test score (ACT) was $19.9 \pm 3.6$ in Korea study compared to patients in present study $13.68 \% \pm 6.150$ ). A study in 2017 was conducted at three cities from Saudi Arabia (Riyadh, Jeddah, and Alkhobar) the prevalence of depression among adult asthmatic patients was $20 \%$ (30 cases $/ 150$ patients), which is lower than this study ${ }^{\mathbf{( 1 1 )}}$. This reported a lower rate of depression may be because they used smaller sample size (150 adult asthmatic patients) and included younger age group 34 year versus 41 year in the present study. Also, they used hospital anxiety and depression scale (HADS) to assess depression, which is different from the measure of depression in current study PHQ-9.

Another study in 2012 conducted in Egypt found the prevalence of depression in patients with asthma was $13.3 \%$ which is lower than this study ${ }^{(20)}$. This lower rate may be due to that the sample size was 98 asthmatic patients, which is smaller than current study and they recruited patients from Outpatient Chest Clinic at Al-Zahraa University Hospital, which is different from this study that conducted in the hospital specialized for chest diseases. Also, they used the Beck Depression Inventory (BDI) to assess depression, which is different from the measure of depression in current study PHQ-9. A study by Tafti et al. $^{\text {(21) }}$ showed that the prevalence of depression was $65.4 \%$, which is higher than this study. This higher rate may be because they used a different measure of depression which is 28 -item general health questionnaire (GHQ-28), which has lower sensitivity and specificity (83 \%, 78\% respectively) compare to $88 \%, 88 \%$ respectively for PHQ-9 which was used in the current study. A study by Misra et al. ${ }^{(22)}$ found that the prevalence of depression in patients with asthma was $65 \%$ which is higher than this study. This higher rate may be due to that they used a sample size of 100 asthmatic patients, which is smaller than current study and they recruited patients from the department of pulmonary medicine at tertiary care hospital that may receive severe cases of asthma. Also, they used the Beck Depression Inventory (BDI) to assess depression which is different from the measure of depression in current study PHQ-9.

A study in 2003 was conducted in Australia showed that the prevalence of depression was $22.1 \%$ that is lower than this study ${ }^{(23)}$. This lower prevalence reported in Australia may be because they used the PRIME-MD instrument to assess depression, which is different from the measure of depression in the current study PHQ-9. In 2015 a study by Ciprandi et al. ${ }^{(\mathbf{1 0 )}}$, in Italy showed that the prevalence of depression was $11 \%$ that is lower than this study. This lower prevalence reported in Italy may be due to that their sample included patients with better control asthma (high mean asthma control test score(ACT) $20 \pm 4.4$ in Italy compared to patients in present study $13.68 \% \pm 6.150$ ). Also, they used hospital anxiety and depression scale 
(HADS) to assess depression which is different from the measure of depression in current study PHQ-9.

A study (2010) in Brazil found that the prevalence of depression in patients with asthma was $53 \%$, which is higher than this study ${ }^{(24)}$. This higher rate may be due to that the sample size was 78 asthmatic patients, which is smaller than current study and they recruited patients from Asthma Outpatient Clinic of at tertiary care hospital that may receive severe asthma cases. Also, they used hospital anxiety and depression scale (HADS) to assess depression, which is different from the measure of depression in current study PHQ9.

A study in Mexico (2006) found that the prevalence of depression among asthmatic patients was $8 \%$, which is lower than this study ${ }^{(25)}$. This reported rate may be because they used a smaller sample size of 60 asthmatic patients and included younger age group (34 year versus 41 year in the present study). Also, they used hospital anxiety and depression scale (HADS) to assess depression, which is different from the measure of depression in the current study PHQ-9.

The present study in the univariate and multivariate analyses showed a significant association between lower education level and depression in adult asthmatic patients. The lower the education level the higher the rate of depression. A similar association is found in the study of Choi et al. ${ }^{(26)}$ in Korea and the study by Tafti $\boldsymbol{e t}$ al. ${ }^{(21)}$ in Iran.

In the current study, the univariate analysis showed that age was not significantly associated with depression. Similar result is found in the study by Ciprandi et $\boldsymbol{a l} .{ }^{(10)}$ in Italy and a study in Turkey ${ }^{(27)}$. However, another study de Miguel Díez ${ }^{(28)}$ in Spain found older age was associated with depression among adult asthmatic patients.

The present study, in the univariate analysis, showed that married subjects had a higher prevalence of depression than single. Similar result is found in a study in Turkey ${ }^{(29)}$. However, in multivariate, there was no significant association.

In current study, univariate analysis showed the significant association between poor asthma control and high prevalence of depression, which is also reported in the study of Ciprandi et al. ${ }^{(10)}$ in Italy and the study of Choi et al. ${ }^{(19)}$ in Korea. However, in multivariate analysis there was no significant association.

In the present study, both univariate and multivariate showed that the longer asthma duration was associated with higher prevalence of depression. Similar result is found by Al-Habboo et al. ${ }^{(9)}$.

There are some limitations to the present study; first, limitation it was not a community-based study, it was carried out in one chest hospital in Jizan region. This may explain the high prevalence of depression in this study. However, this hospital serves most asthmatic patients in Jizan region. Second, the depression was evaluated by a questionnaire and not by a clinician, although PHQ-9 questionnaire is a good depression screening method.

\section{CONCLUSION}

The study showed that there was a high prevalence of depression among adult asthmatic patients in Jizan region, Saudi Arabia. The higher prevalence of depression was associated with lower education level, longer asthma duration, poor control of asthma and among married subjects.

\section{Financial support and sponsorship: Nil. Conflict of interest: Nil.}

\section{REFERENCES}

1. World health organization (2021): Asthma fact sheet. http://www.who.int/mediacentre/factsheets/fs307/en/

2. Al-Moamary M, Alhaider S, Idrees $M$ et al. (2016): The Saudi Initiative for Asthma - 2016 update: Guidelines for the diagnosis and management of asthma in adults and children. Annals of Thoracic Medicine, 11 (1): 3-42.

3. Moradi-Lakeh M, El Bcheraoui C, Daoud F et al. (2015): Prevalence of asthma in Saudi adults: findings from a national household survey, 2013. BMC Pulmonary Medicine, 15: 77-82.

4. Mental Health Foundation (2021): Depression. https://www.mentalhealth.org.uk/a-to-z/d/depression

5. World Health Organization (2018): Depression fact sheet. http://www.who.int/mediacentre/factsheets/fs369/en/

6. Al-Qadhi W, Rahman S, Ferwana M et al. (2014): Adult depression screening in Saudi primary care: prevalence, instrument and cost. BMC Psychiatry, 14 (1): 190-94.

7. Maurer D (2012): Screening for depression. Am Fam Physician, 85 (2): 139-44.

8. Bhowmik D, Kumar K, Srivastava S et al. (2012): Depression - Symptoms, Causes, Medications and Therapies. The Pharma Innovation, 1 (3): 37-51.

9. Al-Habboo D, Sultan K, Najim Z et al. (2017): Psychiatric Manifestation of Patients with Bronchial Asthma in Mosul, Iraq. Psychiatr Danub., 29 (3): 649-51.

10. Ciprandi G, Schiavetti I, Rindone E et al. (2015): The impact of anxiety and depression on outpatients with asthma. Annals of Allergy, Asthma \& Immunology, 115 (5): 408-14.

11. Allam A, Rawy A, Abdeldayem O et al. (2017): Prevalence of anxiety and depression in patients with airway obstruction using hospital anxiety and depression scale (HADS) in different localities of Saudi Arabia. Egyptian Journal of Chest Diseases and Tuberculosis, 66 (4): 617-22.

12. Kullowatz A, Kanniess F, Dahme B et al. (2007): Association of depression and anxiety with health care use and quality of life in asthma patients. Respiratory Medicine, 101 (3): 638-44.

13. Pourhoseingholi M, Vahedi M, Rahimzadeh $M$ (2013): Sample size calculation in medical studies. Gastroenterology and Hepatology From Bed to Bench, 6 (1): 14-7.

14. Schatz M, Sorkness C, Li J et al. (2006): Asthma Control Test: Reliability, validity, and responsiveness in 
patients not previously followed by asthma specialists. Journal of Allergy and Clinical Immunology, 117 (3): 549-56.

15. Thomas M, Kay S, Pike J et al. (2009): The Asthma Control Test (ACT) as a predictor of GINA guidelinedefined asthma control: analysis of a multinational crosssectional survey. Prim Care Respir J., 18 (1): 41-9.

16. Health Authority in Abu Dhabi (2020): Asthma control test (for 12 years or older). https://www.doh.gov.ae//media/4AD16536E1764ED7BB44D1E918515B3A.ash $\mathrm{X}$

17. Kroenke K, Spitzer R, Williams J (2001): The PHQ-9: validity of a brief depression severity measure. J Gen Intern Med., 16 (9): 606-13.

18. Alhadi A, Alateeq D, Al-Sharif E et al. (2017): An arabic translation, reliability, and validation of Patient Health Questionnaire in a Saudi sample. Annals of General Psychiatry, 16 (1):32-35.

19. Choi G, Shin Y, Kim J et al. (2014): Prevalence and risk factors for depression in Korean adult patients with asthma: is there a difference between elderly and nonelderly patients? J Korean Med Sci., 29 (12): 1626-31.

20. Farag T, Hafez M, Abo-Elkheir T (2012): Anxiety and depression among patients with Bronchial asthma, chronic obstructive pulmonary disease and diffuse parenchymatous lung diseases. The Egyptian Journal of Hospital Medicine, 49: 718-731.

21. Tafti S, Cheraghvandi A, Safa M et al. (2011): Study of depressed mood and quality of life in asthma patients in Tehran using the 28-item general health questionnaire. East Mediterr Health J., 17 (11): 838-42.

22. Misra S, Kundu S, Majumder D et al. (2015): A Study of Depression in Adult Patients with Bronchial Asthma Presenting to a Tertiary Care Hospital in Eastern India. Indian J Chest Dis Allied Sci., 57 (2): 87-90.

23. Goldney R, Ruffin R, Fisher L et al. (2003): Asthma symptoms associated with depression and lower quality of life: a population survey. Med J Aust., 178(9):437-41.

24. Vieira A, Santoro I, Dracoulakis S et al. (2011): Ansiedade e depressão em pacientes com asma: impacto no controle da asma. Jornal Brasileiro de Pneumologia, 37: 13-8.

25. Espinosa Leal F, Parra Roman M, Mendez $N$ et al. (2006): Anxiety and depression in asthmatic adults in comparison to healthy individuals]. Revista alergia Mexico. Tecamachalco, Puebla, Mexico, 53: 201-206.

26. Choi S, Kim S, Lee J (2017): Association between depression and asthma in Korean adults. Allergy Asthma Proc., 38 (3): 37-46.

27. Özcan A, Dursun A, Cicek T (2015): The comparison of anxiety and depression levels in asthma and COPD patients. The World Allergy Organization Journal, 8 (1): 51-55.

28. de Miguel Díez J, Hernández Barrera V, Puente Maestu L et al. (2011): Psychiatric comorbidity in asthma patients. Associated factors. Journal of the Association for the Care of Asthma, 48 (3): 253-8.

Yakar T, Baran A, Gungor S et al. (2007): The factors affecting Beck depression scale in asthmatic patients. Tuberk Toraks, 55 (1): 11-17. 